\title{
Small, micro and medium enterprises financing: Costs and benefits of lending technologies in the Eastern Cape province of South Africa
}

Authors:
Edson Mbedzi ${ }^{1}$
Munacinga Simatele ${ }^{1}$
Affiliations:
'Department of Economics,
University of Fort Hare,
East London, South Africa
Corresponding author:
Edson Mbedzi,
201615007@ufh.ac.za
Dates:
Received: 08 May 2019
Accepted: 06 Mar. 2020
Published: 20 July 2020
How to cite this article:
Mbedzi, E. \& Simatele, M.,
2020, 'Small, micro and
medium enterprises
financing: Costs and benefits
of lending technologies in the
Eastern Cape province of
South Africa', Journal of
to read online.
Economic and Financial
Sciences $13(1)$, a477. https://
doi.org/10.4102/jef.
v13i1.477
Copyright:
Co 2020. The Authors.
Licensee: AOSIS. This work
is licensed under the
Creative Commons
Attribution License.

Orientation: As lack of access to credit hinders small, micro and medium enterprises (SMMEs) success and lending technologies being conduits transmit credit access, more focus must be on the effect of lending technologies on credit rationing.

Research purpose: To analyse the extent of credit rationing amongst SMMEs based on lender and firm characteristics.

Motivation for the study: In South Africa, SMMEs are funded by different lenders using different lending technologies, but little is known about which ones are more effective.

Research approach/design and method: The study takes a quantitative approach. In this study, 321 SMMEs are sampled from 1486 small businesses on the registers of the Nelson Mandela Bay Business Chamber and the Border-Kei Chamber of Business in the Eastern Cape province of South Africa. Financing of SMMEs is captured with a categorical credit-rationing variable. Accordingly, a logit technique is used. The first model captures credit rationing as a binary variable. In the second model, the nature of credit rationing is disaggregated resulting in a four-measure categorical variable.

Main findings: Little rationing occurs when asset-based and venture capital methods are used. Microfinance and privately owned development financial institutions have high rationing levels, similar to commercial banks, defeating the purpose of their special existence to address excluded groups. Black people-owned and female-owned businesses are the most rationed. Credit rationing decreases with firm size, but the effects are amplified by race.

Practical/managerial implications: To improve SMMEs access to finance, the government should focus on allocating funds to firms using SMMEs' credit rationing risk profiles.

Contribution/value-add: Lending technology, lender type and SMME characteristics relationships indicate that SMMEs can benefit from a well-understood rationing risk profile of firms in the economy. Therefore, policies on support and regulation of the distribution of loan portfolios aligned to empirical rationing risk profiles can improve SMME growth. However, this study has used SMME data from the Eastern Cape province only, one of the nine provinces in South Africa. Thus, the provincial heterogeneity effects are not captured in this study.

Keywords: lending technologies; SMME structure; lender structure; credit rationing; Eastern Cape.

\section{Introduction}

The literature provides a significant amount of evidence that small, micro and medium enterprises (SMMEs) are critical to the growth of many economies (Ayyagari, Demirguc-Kunt \& Maksimovic 2011; Nassr \& Wehinger 2014). Nevertheless, evidence shows that many SMMEs are credit rationed and consequently the attrition rate is very high especially in developing countries (Makinaet al. 2015). Mainstream lenders such as banks tend to rely on transaction-based lending that primarily uses hard financial data from audited financial statements as well as credit scores gathered from the financial histories of the firms. Small, micro and medium enterprises, however, often have poor financial records and are informationally opaque resulting in credit rationing (Makina et al. 2015; Uchida, Udell \& Yamori 2012). Consequently, they are more often suited to relationship lending technologies. Such technologies rely more on soft qualitative data acquired from repeated interactions with the small firms and the communities around them (Casey \& O’Toole 2014; Comeig, Fernández-Blanco \& Ramírez 2015; Uchida et al. 2012). 
Recent practices have revealed that new lending technologies are not necessarily based on relationships. These circumvent several of the constraints posed by SMME information opacity and lack of collateral (Berger \& Udell 2006). Using these technologies, larger institutions can provide finance to smaller borrowers (De la Torre, Martínez Pería \& Schmukler 2010). However, Berger and Udell (2006) argue that using the dichotomy between large and small lenders as a predictor of lending is over simplistic. A spectrum of lending technologies exists and neither group has equal advantages on all technologies (Bartoliet al. 2013; Berger \& Black 2011). Rather, borrower characteristics, institutions and technologies all interact to influence lending decisions.

Accordingly, this article investigates how these factors interact to determine the choice of lending technologies and how they, in turn, affect credit rationing of SMMEs in South Africa. The study is therefore guided by the following objectives. The first is to estimate the impact of lender and firm characteristics on the level of credit rationing endured by SMMEs. The second is to determine whether the observed credit rationing of SMMEs is at least, in part, affected by the type of lending technology used.

The South African government considers the growth of SMMEs critical to stimulating growth in the economy and a primary driver of job creation and inclusive growth. The government subsequently established a number of financial institutions and created support structures that incorporate both private and public sector financial institutions to increase financial access to SMMEs. The Ministry of Small Business Development established in 2014 aids this process. Two main contributions suggest reasons for these government efforts. Firstly, SMMEs must understand factors accounting for the level of credit rationing they endure and thus must advance internal capacity developments that reduce credit rationing burden. Secondly, the government must understand the credit rationing risk profiles experienced by SMMEs and then propose policies directly dealing with that as well as aligning government earmarked financing programmes to well-known SMMEs' credit rationing risk profiles. An understanding of the factors that determine the choice of lending technologies is an important step in providing policy insights into how credit rationing can be minimised for small businesses and therefore enhancing benefits of SMMEs within the country. Section 2 of this article provides a brief review of the literature on lending technologies and credit rationing of SMMEs. Section 3 discusses the methods and data used. In Section 4, results are presented and Section 5 concludes the article.

\section{Literature review}

Credit rationing occurs when market disequilibrium exists forcing lenders to either supply less credit than is required, offer credit at high interest rate or reject credit applications outrightly (Adair \& Fhima 2014). Because of small size, SMMEs can access neither financial markets nor capital markets (Berger \& Udell 2006) and depend solely on intermediated financing as the main source of external funding. Credit rationing is seen as a form of market failure caused by adverse selection (Helsen \& Chmelar 2014). Whenever intermediary financial institutions are the main source of financing, some elements of credit rationing exist. This tends to be worse for SMMEs owing to their information opacity. The limited options for funding sources amplify rationing. For example, out of 200 SMMEs surveyed in Bangladesh, only $60 \%$ obtained bank loans ( $40 \%$ credit rationing) and of those obtaining loans, 19\% were credit quantity rationed and 29\% interest risk rationed (Hoque, Sultana \& Thalil 2016).

Factors influencing the choice of lending technologies used also stimulate credit rationing for SMMEs. Lender characteristics such as bank size (Bartoli et al. 2013; Berger \& Black 2011; Degryse \& Van Cayseele 2000), bank type (Aysanet al. 2016; Viveritaet al. 2015) and bank operational structures (Cotugno, Monferrà \& Sampagnaro 2013; Shenet al. 2009) influence types of lending technologies used in each market. Subsequently, these lender characteristics are related to credit rationing of SMMEs in those countries.

The types of banks in a market affect lending technologies and the level of credit rationing that follows. By far, large banks mostly lend to large firms using transaction lending technologies based on hard information, while small banks have an advantage in lending to small firms using relationship lending technology (Aysan et al. 2016; Degryse \& Van Cayseele 2000). However, advantages of both large and small banks are not uniform across all firm sizes, advantages of large banks do not necessarily increase with firm size, whereas for small banks the benefits of relationship advantages increase with the size of small firms (Berger \& Black 2011; Hoque et al. 2016). Similarly, small banks with less hierarchical levels lend more to SMMEs compared to large banks (Luo \& Zhou 2016; Shen et al. 2009), asserting the view that small banks are associated with less credit rationing of SMMEs compared to large banks.

While bank size is highly correlated with credit rationing of SMMEs, specific bank strategies adopted can reduce this risk for large banks as well. For instance, decentralised large banks also have the same advantages as small banks in serving SMMEs provided their decentralised branch offices have high self-loan approval rights (Shen et al. 2009). This advantage to SMMEs must not be limited by competition and market power of banks (Canales \& Nanda 2012) or by distance between the bank's branch office and SMMEs, which limits transmission of soft information beneficial for SMMEs lending (Cotugno et al. 2013). Bank size in this case influences the types of lending technologies adopted and the ensuring level of credit rationing associated with each form of lending technology.

Lending technologies can also be influenced by the financial system of the economy (Jiangli, Unal \& Yom 2004). For instance, the market-based financial system in the United States has more credit access to large firms, but is accompanied 
by fewer relationships with financial institutions, whereas the bank-based financial system in Europe and Japan exhibits more credit access to small firms associated with more relationships with financial institutions. As a result, the structure of the financial system not only has a bearing on the scope of the relationships created, but also determines SMMEs' credit access (Berger \& Udell 2002). Consequently, based on local economic conditions shaping the existing lending institutional structure, lenders use different lending technologies that are amenable to the lending institutional structure in place.

Various lending technologies are also adopted on the basis of economic structure. Economic structures can be either rural or urban (Luo \& Zhou 2016; Makina et al. 2015). The structure may also be based on either factor-driven, efficient-driven or innovation-driven economy (Meuleman \& De Maeseneire 2012). Whichever structure of the economy, the extent of government involvement in the economy through subsidies and credit guarantees (Nkuah, Tanyeh \& Kala 2013; Trovato \& Alfo 2006) influences the types of lending technologies lenders use in line with existing national economic structural conditions. How these lending technologies applied in each of the cases influence credit rationing? For example, in economies where there is high subsidies and government loan guarantees, credit access is increased. Similarly, the nature of legislation and the extent of commercial law enforcement in economies determine the level of applicability of certain types of lending technologies. For example, assetbased lending became very popular in the United States owing to the ease of the commercial law affecting assignment and registration of assets (Beck \& Demirguc-Kunt 2006) and subsequently increased credit access to small businesses. It is important to note, however, that economic structures are only relevant when making comparisons in different economies or within economies where such structures vary significantly among different regions or provinces. So, within one small economy or one province these factors tend to be static, thereby affecting different economic players the same way.

Finally, the structure of the SMMEs influences types of lending technologies lenders use and credit rationing that follows. Firm structures, like debt structure, influence lending technologies suitable to support existing levels of debt (Kundid \& Ercegovac 2013). The level of development of SMMEs (Kimutai \& Ambrose 2013) and that of appetite firms have for credit (Mac, Vidal \& Lucey 2016) are some of the firm structures that force lenders to adopt particular lending technologies when dealing with such firms, thereby affecting the amount of credit that lenders can offer.

\section{Data and research design}

In building the conceptual framework for SMME lending, we borrow information from the asymmetric information theory (Stiglitz \& Weiss 1981), and advance the fact that lending to SMMEs hinges on lending technologies used, which in turn are subject to the level of information available to the potential lender (Allen 2016; Butler, Kraft \& Weiss 2007; Mac et al. 2016; Mullen 2012; Ravi \& Hong 2014). From that analogy, we propose that credit rationing is a function of the costs and benefits associated with each type of lending technology.

Lender, SMME and economic structures, whose main components are summarised in Figure 1, in turn determine these different technologies. The study therefore follows a quantitative approach to measure the effects.

Lenders' structures are entrenched in types of financial institutions (Kanoet al. 2011; Uchida \& Udell 2006; Uchida et al. 2012), size and ownership (Allen 2016; Korkeamaki, Poyry \& Suo 2014; Ravi \& Hong 2014) and lender-specific strategies (De la Torre et al. 2010). These factors determine a lender's choices of suitable lending technologies to use. Similarly, lending technologies selected must fit into countryspecific economic structures. The economic structures include financial systems that are either market-based or bank-based (Memmel, Schmieder \& Stein 2008), depth of the bank legal system to support loan contracts (Koreen \& Lucia 2015; Mac et al. 2016), level of government support and the types of industry bases in the economy. Lastly, lending technology types are influenced by the level of the development of SMMEs by size, age, activity levels, sectors and areas in which they are located (Makina et al. 2015). Based on determinants of lending technologies and type of lending technologies' relationship, we hypothesise that lending technologies used have a direct impact on the outcome of lending. The application of different lending technologies in SMME financing has two implications; firms benefit by growing when credit rationing is low and suffer survival costs when credit rationing is high (Figure 1).

\section{Data}

Data used in the study are based on a survey conducted in the Eastern Cape province of South Africa. The economic structural variation that may arise between different

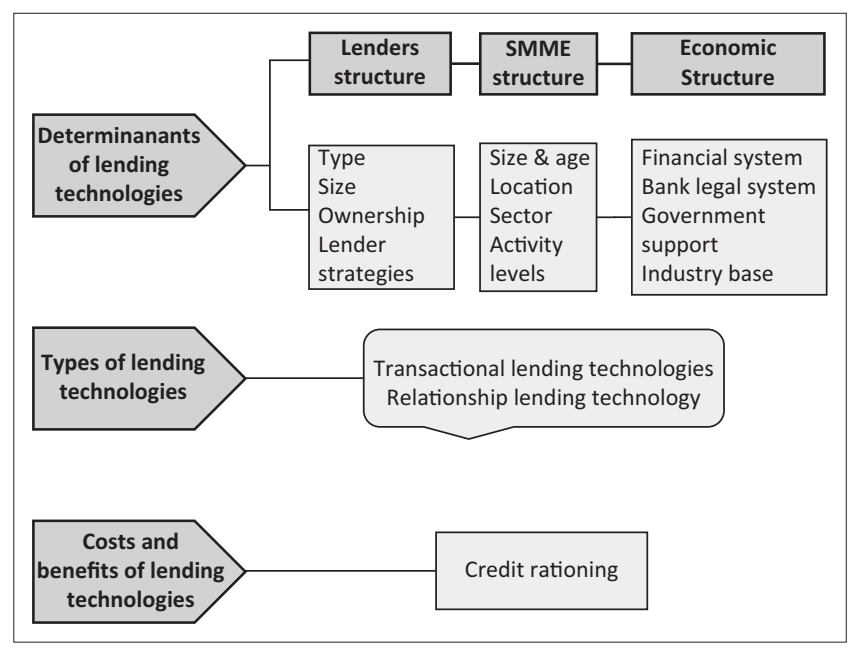

SMMEs, small, micro and medium enterprises.

FIGURE 1: Small, micro and medium enterprises lending framework. 
provinces is therefore not covered in this article. The model for this study was developed based on this reasoning to inform the variables analysis map (Figure 2).

As of 20 June 2017, the Nelson Mandela Bay Business Chamber and Border-Kei Chamber of Business registers had a total population of 1486 firms (721 and 765, respectively) and over $75 \%$ of the firms were SMMEs (BKCOB 2017; NMBBC 2017). Business databases of both chambers had each firm's contact details comprising company name, telephone number, e-mail address, website and physical address arranged sector by sector. This made it easy to contact and physically locate the firms. Cochran's sample size for categorical data (Bartlett, Kotrlik \& Higgins 2001) was used to estimate the minimum sample size of 305 for the study. The sample was stratified based on metropolitan location and sector-type population representation. Consequently, the sample comprises sorely of formal and registered SMMEs. Data were collected from 322 SMMEs in Border Kei and Nelson Mandela Bay metropolitans in the Eastern Cape province of South Africa between 28 July 2017 and 30 September 2017. Summary statistics of these sample firms are presented in Table 1. One firm was dropped because its annual turnover was above the National Small Business Act (29) of 2004 SMME classification. Small, micro and medium enterprises in the sample were in operation for 1 and 57 years with owner experience from 2 to 53 years. Firms that were in operation for a long time resulted in client-lender relationships that exceed 50 years. The maximum annual sales recorded include R56 077 140, capitalisation over

\begin{tabular}{|l|l|l|}
\hline \multicolumn{1}{|c|}{ Independent variables } & \multicolumn{1}{|c|}{$\begin{array}{l}\text { Independent variables } \\
\text { determining structures }\end{array}$} \\
\hline $\begin{array}{l}\text { Lending technologies } \\
\text { Types of lenders } \\
\text { Type of owner structure } \\
\text { Race of SMME owner/s }\end{array}$
\end{tabular}

SMMEs, small, micro and medium enterprises.

FIGURE 2: Variables analysis map.
R40 000000 and annual capital investments averaging R225 000. Of the 321 SMMEs in the sample, 190 accessed loans during the period under study ranging between R10 000 and R5 650000 in amount. Sources of loans varied and included trade finance.

\section{Definition of variables}

Credit rationing is used as the dependent variable measured alternately as a dichotomous variable and as a categorical variable. The dichotomous measure takes the value of 1 if the SMME has experienced credit rationing of any form and 0 otherwise or as a categorical variable taking the value of 1 if the firm experienced an outright rejection, the value of 2 if there was quantity rationing and the value of 3 if there was price rationing or 0 otherwise. The independent variables include types of lending technologies, firm size as measured by sales revenue, race and gender of firm owner, type of ownership structure, as well as lender type.

Four types of lending technologies are identified. These were derived from a list of concepts informing all potential lending technologies. Small, micro and medium enterprises were asked to indicate whether these concepts applied or not in their interaction with their lending institutions during the lending process. The type of technology attributed to a firm was determined by looking at the dominant lending concepts applied. For instance, if an SMME received a loan based on cash flow, profitability or asset value information it provided the lender, that is, items ordinarily captured in a financial statement, then financial statement lending was used in funding that SMME. However, if the same SMME alludes that in addition to the above requirements, it further lodged any other form of an asset as security, then asset-based lending technology is assumed even if some of the financial statement concepts still apply. Similarly, if the SMME also asserts that, in addition to any of the above concepts, the lender retained part ownership of the business as part of the lending deal, then venture capital lending overrides all the previous methods. Finally, if all or part of the above applies, but lending was for a specific serialised asset, then asset financing lending technology is assumed.

TABLE 1: Summary statistics.

\begin{tabular}{|c|c|c|c|c|c|}
\hline SMME attributes & $\mathbf{N}$ & Min & Max & Mean & Standard deviation \\
\hline Age of firm in years & 321 & 1 & 57 & 9.8 & 8.08 \\
\hline Experience of owner in years & 321 & 2 & 53 & 14.8 & 10.12 \\
\hline Number of employees of SMME & 321 & 2 & 192 & 25 & 37 \\
\hline Total annual sales of SMME & 301 & 76820 & 56077140 & 3118633 & 8233790 \\
\hline Total value of assets of SMME & 287 & 5300 & 49041860 & 1442145 & 4745277 \\
\hline Amount of loans to SMME & 190 & 10000 & 5650000 & 315337 & 708485 \\
\hline Total annual capital investment & 253 & 2700 & 6491350 & 225685 & 653406 \\
\hline Total value of capital investment & 233 & 1000 & 9000000 & 370332 & 995243 \\
\hline Creditors days offered to SMME & 321 & 0 & 90 & 19 & 19 \\
\hline Debtors days offered by SMME & 319 & 0 & 90 & 17 & 21 \\
\hline Length of bank relationship in years & 316 & 1 & 53 & 7.99 & 7.17 \\
\hline Bank staff visits per year & 123 & 1 & 4 & 1.78 & 1.43 \\
\hline
\end{tabular}

All monetary values are in the South African rand.

SMMEs, small, micro and medium enterprises. 
The type of ownership structure included four categories. These include sole-trader male-owned, sole-trader female-owned, family-owned or partnership-owned businesses. Firm size was defined as per the Small Business Act classification of small businesses in South Africa (National Small Business Act (29) of 2004). The primary items used to determine size were the number of employees, annual sales and value of assets. Each SMME was then fitted into the respective firm size category, which is either micro, small, very small or medium. The last independent variable is race of owners of the SMME. Following the South African census race categories, four groups were identified that include black people, white people, Indian people and mixed race people.

\section{Estimation model}

Following the hypothesis depicted in Figure 1 earlier, characteristics of lenders and borrowers interact to influence lending technologies chosen and ultimately the choice of whether to lend or not, as well as how much to lend if the decision is taken to do so. The empirical analysis uses a logit regression model to estimate the likelihood of credit rationing given a specific variable. Rationing is measured as a dichotomous variable, which takes the value of 1 if the SMME has experienced credit rationing of any form within the sample period and 0 otherwise. This is estimated as shown in Equation (1).

$y=\alpha+\beta_{1} X+\beta_{2} Z+\varepsilon$

$y=\left\{\begin{array}{l}1 \text { if firm } i \text { was credit rationed } \\ 0 \text { if firm } i \text { was not credit rationed }\end{array}\right\}$

An alternative measure is a categorical variable taking the value of 1 if there was an outright rejection, the value of 2 if there was quantity rationing and the value of 3 if there was price rationing by charging an interest rate higher than the average prime rate of $10.25 \%$ in the year 2017. This representation is shown in Equation (2).

$y=\alpha+\beta_{1} X+\beta_{2} Z+\varepsilon$

$y=\left\{\begin{array}{l}1 \text { if } i \text { faced outright credit rejection } \\ 2 \text { if } i \text { was quantity credit rationed } \\ 3 \text { if } i \text { was price credit rationed } \\ 0 \text { if } i \text { was not credit rationed }\end{array}\right.$

$\mathrm{Y}$ is the dependent variable and is measured by credit rationing.

$X$ includes the lender characteristics, including the type of lending institution and technology used to fund firm $i$.

$Z$ represents the vectors of control variables based on firm attributes including firm size, type of ownership structure and race group of owners associated with firm $i$. In addition, the historical realities of South Africa have shown that race plays an important role in many economic activities of the country. Race is therefore included as one of the regressors.

$\varepsilon=$ is the vector of heteroskedasticity-robust standard errors.

\section{Ethical considerations}

This article followed all ethical standards for research without direct contact with human and animal subjects. An ethical clearance certificate number SIM031SMBE01 was issued by the University Research Ethical Committee of the University of Fort Hare in respect of the study.

\section{Results}

The article proceeds by first estimating the factors affecting overall credit rationing. Older and larger firms are more likely to have access to formal finance. The age of the firms, experience of the owner and number of employees are therefore expected to be negatively related to credit rationing. Four separate models are estimated. The lender variable is measured as a categorical variable including commercial banks, development finance institutions and microfinance institutions. Commercial bank is used as the base category in the estimations. As a result, coefficients on government-owned lending and microfinance institutions are expected to be negative as they are specifically designed to increase lending to financially excluded firms.

Four models are estimated. Models (1) and (2) are based on Equation (1). Model (1) is the base model, which includes the main variables highlighted above. The study hypothesises that because of historical influences, the impact of some variables is likely to be magnified or minimised if it nests an additional effect of race. For example, white people-owned businesses are less likely to be credit rationed because they have a much longer history with lending institutions than black people-owned businesses. Model (2) captures the additional effect of race by interacting race with size of the firm and lender structure. Models (3) and (4) are estimated based on Equation (2) to delineate the effects of the explanatory variables on the different types of credit rationing and therefore address the second objective. Model (3) is estimated without interaction variables while these are included in Model (4). The estimation followed a stepwise process to allow for the addition of interaction variables in both equations. The results showing the level of credit rationing of SMMEs based on the lender and SMME structural independent variables are presented in Tables 2 (Models 1 and 2), 3 and 4 (Models 3 and 4, respectively). For parsimony, statistically insignificant variables were tested for relevance and dropped where tests indicated no adverse effect on the model. Diagnostics indicate that all the models are specified. 
TABLE 2: Small, micro and medium enterprises and lender characteristics effects on credit rationing.

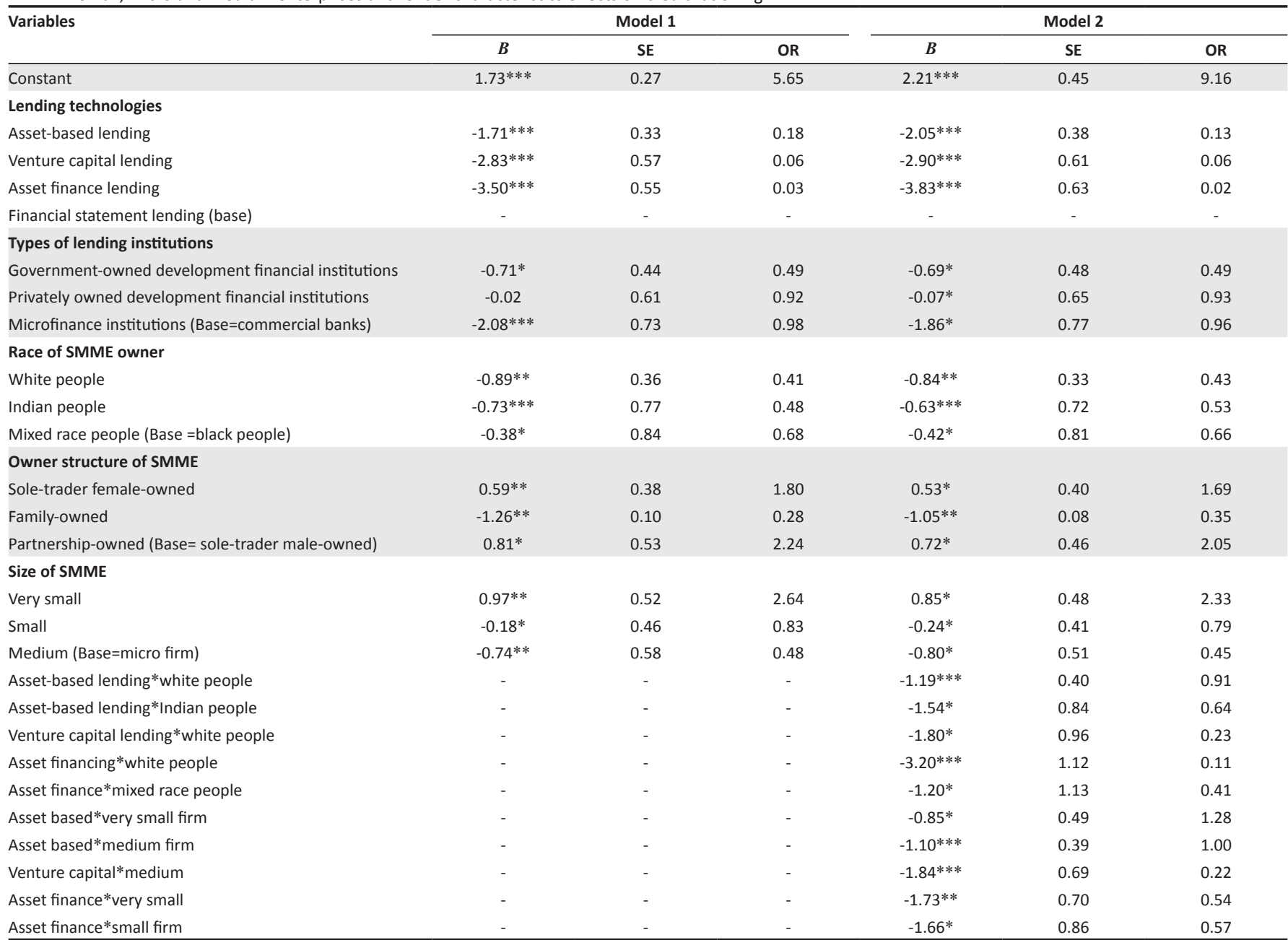

Note: Model 1 test results: -2 LsL test 301.395; Omnibus test $\chi^{2}=143.985, d f=7, p<0.005$; Nagelkerke $R_{2}=48.1 \%$; Hosmer-Lemeshow goodness of fit test $p=0.735$; Classification accuracy = $72.3 \%$. Model 2 test results: -2 LsL test $=269.230 ;$ Omnibus test $\chi^{2}=176.15, d f=17, p<0.05$; Nagelkerke $R_{2}=56.2 \%$; Hosmer-Lemeshow goodness of fit test $p=0.380 ;$ Classification accuracy $=$ $79.5 \%$

SMMEs, small, micro and medium enterprises; $B$, beta coefficient; SE, standard error; OR odds ratio.

*, Significance at $10 \%$.

$* *$, Significance at $5 \%$.

***, Significance at $1 \%$

\section{Lending technologies and lender structures}

Financial statement lending is used as the reference category in lending technologies with a base odds ratio of 1 . The odds ratio for each of other types of lending technologies is compared against this reference category (see Table 2). Credit rationing of SMMEs is reduced by 0.87 times when financed using asset-based lending compared to those financed via a financial statement lending. Similarly, credit rationing is reduced by 0.94 times when venture capital lending is used and by 0.98 times when asset finance lending is used compared to financial statement lending. This places asset-based lending, venture capital lending and asset finance lending technologies as better ways of financing SMMEs than using financial statement lending. These results are in tandem with the existing empirical literature (Koreen \& Lucia 2015; Mac et al. 2016) who pointed that asset-based lending provides more benefits to firms than other forms of lending. However, this poses a challenge for small businesses that often lack the required collateral.
The reference category for type of financial institutions is commercial banks. Credit rationing is reduced by 0.50 times when government-owned development financial institutions finance SMMEs instead of commercial banks.

However, credit rationing is reduced only by 0.07 times when financed by privately owned development financial institutions. When microfinance institutions finance SMMEs, credit rationing is only reduced by 0.04 times compared to those financed by commercial banks. As expected therefore, government-owned development financial institutions are better at averting credit rationing of SMMEs. These results concur with existing empirical literature of Aysan et al. (2016) who stated that bank ownership is important in influencing the level of rationing of SMMEs. The existence of government loan guarantees in a market even reduces the credit rationing by about $80 \%$ (Adair \& Fhima 2014; Hoque et al. 2016). This is a great opportunity for South Africa where there are well-established government-owned development financial institutions and a number of SMME-earmarked financing programmes (SEDA 2016, 2017). 


\section{Firm structures and owner characteristics}

The firm structure and owner characteristics considered are race group of the owner, type of ownership structure and size of firm. Black people-owned businesses are used as the reference category for race. These results are shown in Model (2). The credit rationing of SMMEs is increased by 2.33 times for black people-owned SMMEs compared to those that are owned by white people. Similarly, credit rationing increases by 1.89 times for firms owned by black people compared to those owned by Indian people, while credit rationing still increases by 1.52 times for black people-owned enterprises when paralleled against mixed race people-owned businesses. The overall picture is that there still exist high levels of inequality in access to funding for firms owned by individuals in different race groups in South Africa, particularly against black small-business owners. Despite efforts made by the government through the Black Economic Empowerment (BEE) policy, the problem of segregated funding access by race still exists, which is a challenge for the extremely excluded groups.

Ownership structure was referenced against sole-trader male-owned SMMEs. The results in Model (2) indicate that sole-trader female-owned businesses are 1.69 times more credit rationed compared to sole-trader male-owned businesses. Similarly, partnership-owned small businesses are 2.05 times more credit rationed compared to sole-trader male-owned businesses. To the contrary, family-owned small businesses are 0.65 times less likely to be credit rationed compared to sole-trader male-owned businesses. The partnership-owned and sole-trader female-owned businesses were mostly affected by lack of access to credit while familyowned businesses have better access. The business case is that financial institutions view family-owned businesses as having better succession plans firmly rooted from the family bond than partnership-owned or any other form of individually owned businesses. It means several owners insulate credit risk, but this can be diluted by gender. It is, however, surprising that partnerships are worse off than even individually owned businesses. The female entrepreneurs often find it hard to access funding compared to other groups because of gender discrimination (Hansen \& Rand 2014) and similarly partnerships hardly survive beyond 2 years and thus the high failure of this latter group to access finance is therefore empirically supported (Dlova \& Simatele 2016; Hansen \& Rand 2014).

Firm size significantly contributes to credit rationing. Microsized firms are used as the base category. Very small-sized firms were 2.33 times more credit rationed compared to micro-sized businesses. However, small-sized businesses were 0.21 times less likely to be credit rationed compared to micro-sized businesses. Likewise, medium-sized firms were 0.55 times less likely to be credit rationed compared to microsized firms. These results complement both theory and empirical evidence on borrowing of small firms. The market power theory (Cowling \& Westhead 2010) shows credit rationing of firms is inversely related to firm size; thus, the smaller the firm, the more the credit rationing. Furthermore, evidence shows that the level of development of SMMEs as measured in terms of assets value as an indicator of firm size affects credit of small businesses (Kundid \& Ercegovic 2013; Mac et al. 2016).

To get more insight, firm size was interacted with types of lending technologies. The results are shown in Model (2). The results show that among the very small-sized firms, asset-based lending technologies exhibit more credit rationing. This difference disappears, as firm size gets larger. This result underlines the significant role played by scale in lending decisions. The lending technology variable was also interacted with race. The results show that venture capital and asset financing display 0.88 and 0.77 times less rationing than financial statement lending. This pattern is observed for all race groups. For example, 0.36 times less credit rationing is observed among the Indian people when asset-based lending is used and 0.59 times less credit rationing is experienced among the mixed race people using asset financing than when financial statement lending is used. This is intuitive. Both venture and asset financing present less risk than financial statement lending. Moreover, the lack of relevant financial statements among SMMEs is likely to foster credit rationing. The results indicate while lending technology affects credit rationing of SMMEs, ownership structure enhances the effect of a lending technology used. For example, what is emerging is an important factor that lending technology affects the probability of being rationed as well as that exacerbated by ownership structures.

\section{Firm structures and types of credit rationing}

To further probe the effect of ownership structure on credit rationing of firms, credit rationing was split into three categories that include complete rationing where an applicant is completely denied a loan, quantity rationing where an applicant is lent less than the amount applied for and price rationing where a higher than average market interest rate is charged. These results are shown in Models (3) and (4) in Tables 3 and 4, respectively. Model (3) shows how the type of ownership and firm size variables influence credit rationing while Model (4) adds interaction variables. Some of the variables in Models (1) and (2) were dropped in estimating Models (3) and (4) because of loss of data in categorising the rationing variable.

Sole-trader male-owned businesses were 0.62 times less likely to be subjected to a straight denial, 0.64 times less likely to be quantity rationed and 0.05 times less likely to be price rationed compared to partnership-owned businesses. While soletrader female-owned firms were also 0.62 times less likely to experience straight denial, but only 0.57 times less likely to be quantity rationed and 0.27 times less likely to face price rationing compared to partnership-owned businesses. Familyowned businesses were 0.85 times less likely to be denied a loan, 0.84 times less likely to be quantity rationed and 0.86 times less likely to be priced rationed compared to partnership firms. The results further affirm that individually owned 
TABLE 3: Small, micro and medium enterprise structural effects on type of credit rationing of small, micro and medium enterprises.

\begin{tabular}{lccc}
\hline Model 3 & $\begin{array}{c}\text { Direct denial } \\
\text { (OR) }\end{array}$ & $\begin{array}{c}\text { Quantity rationed } \\
\text { (OR) }\end{array}$ & $\begin{array}{c}\text { Price rationed } \\
\text { (OR) }\end{array}$ \\
\hline Constant & $(-1.75)^{* * *}$ & $(-0.90)^{*}$ & $(-2.27)^{* * *}$ \\
Owner structure of SMME & & & \\
Sole-trader male-owned & $0.38^{* *}$ & $0.36^{* *}$ & $0.95^{*}$ \\
Sole-trader female-owned & $0.38^{* *}$ & $0.43^{*}$ & $0.73^{*}$ \\
Family-owned & $0.15^{* * *}$ & $0.16^{* * *}$ & $0.14^{*}$ \\
Partnership-owned (base) & - & - & - \\
Size of SMME & & & \\
Micro & $3.45^{* *}$ & $2.10^{*}$ & $2.11^{*}$ \\
Very small & $2.72^{* * *}$ & $3.61 * *$ & $2.79 *$ \\
Small & $2.14 * * *$ & $1.18^{*}$ & $4.01 *$ \\
Medium (base) & - & - & - \\
\hline
\end{tabular}

Note: Model 3 test results: -2 LL test 152.103; Omnibus test $\gamma^{2}=43.729, d f=18, p<0.05$; Nagelkerke $R^{2} 14 \%$; Likelihood-ratio test $p \leq 0.05$. Classification accuracy $57 \%$.

SMMEs, Small, micro and medium enterprises; OR, odds ratio.

Base category $=$ Not credit rationed.

*, Significant at $10 \%$.

**, Significant at $5 \%$.

***, Significant at $1 \%$

TABLE 4: Small, micro and medium enterprise interaction structural effects on type of credit rationing of small, micro and medium enterprises.

\begin{tabular}{lccc}
\hline Model 4 & $\begin{array}{c}\text { Direct } \\
\text { denial (OR) }\end{array}$ & $\begin{array}{c}\text { Quantity } \\
\text { rationessd (OR) }\end{array}$ & $\begin{array}{c}\text { Price } \\
\text { rationed (OR) }\end{array}$ \\
\hline $\begin{array}{l}\text { Sole-trader male-owned*very } \\
\text { small }\end{array}$ & $(4.09)^{* *}$ & $(1.21)^{*}$ & $(1.62)^{*}$ \\
$\begin{array}{l}\text { Sole-trader male-owned*small } \\
\text { Sole-trader female-owned*micro }\end{array}$ & $(3.35)^{*}$ & $(0.44)^{*}$ & $(0.39)^{*}$ \\
$\begin{array}{l}\text { Sole-trader female-owned*very } \\
\text { small }\end{array}$ & $(3.00)^{*}$ & $(0.69)^{*}$ & $(0.51)^{* * *}$ \\
Family-owned*micro & $(1.18)^{* *}$ & $(0.97)^{*}$ \\
Family-owned*small & $(2.22)^{*}$ & $(0.37)^{*}$ & $(0.81)$ \\
Family-owned*medium & $(2.31)^{* *}$ & $(1.97)^{* *}$ & $(1.51)^{*}$ \\
Partnership-owned*micro & $(1.84)^{*}$ & $(1.66)^{*}$ & $(2.97)^{* *}$ \\
Partnership-owned*very small & $(3.36)^{*}$ & $(3.67)^{*}$ & $(2.61)^{* *}$ \\
Partnership-owned*small & $(2.94)^{* * *}$ & $(3.67)^{*}$ & $(2.92)^{*}$ \\
\hline
\end{tabular}

Note: Model 4 test results: -2 LL test 152.103; Omnibus test $\chi^{2}=43.729, d f=18, p<0.05$ Nagelkerke $R^{2} 14 \%$; Likelihood-ratio test $p \leq 0.05$; Classification accuracy $57 \%$.

$\mathrm{OR}$, odds ratio.

Base category $=$ Not credit rationed

$*$, Significant at $10 \%$

**, Significant at $5 \%$.

$* * *$, Significant at $1 \%$

businesses (either sole-trader male-owned or sole-trader female-owned) suffer more of any form of credit rationing compared to family- and partnership-owned businesses.

Furthermore, micro-sized firms are 3.45 times more likely to experience straight credit denial, 2.10 times quantity rationed and 2.11 times price rationed. Very small-sized firms are 2.72 times more likely subjected to a straight denial, 3.61 times more likely to be quantity rationed and 2.79 times more likely to be price rationed. As for small firms, they are 2.14 times more likely to face straight denial, 1.18 times more quantity rationed, but 4.01 times more price rationed. The results indicate that firm size also segregates firms by type of credit rationing. As firm size increases, firms migrate from punitive conditions of crediting rationing to less punitive conditions of credit rationing. In this case, very small firms face more straight denial, but firms become moderately price quantity at middle size, and only subjected to more price rationing as they move into medium-sized firms.
The firm size variable was also interacted with type of ownership structure. The results are shown in Model (4). The results show that family-owned businesses that are microsized are 2.22 times more likely to face straight credit denial, 0.63 times less quantity rationed and 0.19 times less price rationed, while family-owned businesses that are small-sized are 2.31 times more likely to face straight credit denial, 1.97 times more likely quantity rationed and 1.51 times more likely price rationed. However, family-owned businesses that are medium sized are only 1.84 times more likely to face straight credit denial, 1.66 times more quantity rationed but 2.97 times more likely price rationed. The results further show that partnership-owned businesses that are microsized are massively 3.36 times more likely to face straight credit denial, 3.67 times more likely quantity rationed and 2.61 times more likely price rationed. However, partnershipowned businesses that are small-sized are only 1.14 times more likely to face straight credit denial, but 2.89 and 3.03 times more likely quantity rationed and price rationed. In all the cases, firm size has similar effects. As firm size increases, firms face less straight credit denial but experience more increase in price rationing with moderate changes in quantity rationing. Therefore, firm size transforms the type of credit rationing faced by each type of firm ownership structure from severe direct credit denial to price rationing as firm size increases. Nonetheless, the smaller the firm is, the more these consequences are.

\section{Discussion of results and conclusion}

The results are discussed sequentially below in line with the two objectives of the study.

\section{Small, micro and medium enterprises and lender characteristics affecting credit rationing of small, micro and medium enterprises}

Government-owned development financial institutions and microfinance institutions are more effective in reducing credit rationing when used as vehicles for funding SMMEs. This is not a surprising result as these types of institutions are designed to address the funding gap for SMMEs (Koreen \& Lucia 2015; Mac et al. 2016). The results however showed that when microfinance and development finance intuitions are privately owned, the levels of rationing are very similar to those of commercial banks. This is in line with Dlova andSimatele (2016) who showed that the lending criteria used by development finance microfinance institutions were every similar to those used by commercial banks. The results of this article add to the rising questions of the effectiveness of microcredit and how it can be restructured to better serve the poor and small businesses.

Similarly, when financial institutions use asset-based lending, venture capital lending and asset finance lending technologies, the outcome is associated with less credit rationing of SMME 
than when financial statement lending technology is used. The problem, however, is that these technologies are at odds with the characteristics of SMMEs. Most SMMEs do not have assets to collate rise or consistent audited financial statements that are required for these technologies.

Race has emerged as a significant determinant of access to credit by small businesses. Black people-owned businesses are more likely to be credit rationed compared to those owned by other race groups. White people-owned businesses are the least likely to be credit rationed. These results hold after controlling for both firm and other owner characteristics, as well as lender characteristics. Furthermore, race is observed to amplify the effect of other variables such as firm size and type of lending technology. These results suggest that notwithstanding efforts by the government to correct economic inequalities among the different population groups in South Africa through measures such as the BEE policy, historical inequalities persist in access to finance. This is consistent with finding in the United States where African Americans pay interest rates between 1.7 and 3.38 times higher than other races (Ferguson 2012) and also that borrowers from predominantly black people neighbourhood pay significantly higher contract rate than is consistent with their behaviour (Kau, Keenan \& Munneke 2012).

The results reiterate findings in the literature that small businesses are more likely to be credit rationed. Interacting firm size with ownership type shows that female-owned businesses are most likely to be rationed regardless of the size of the SMME. In a cross-country study, Asieduet al. (2012) show that this problem is unique to sub-Saharan African countries. Hansen and Rand (2014) suggest that this is mainly because of gender discrimination.

\section{Effects of small, micro and medium enterprises and lender characteristics by types of credit rationing}

The effects of SMME and lender characteristics credit rationing were also evaluated based on types of credit rationing experienced by firms. The results affirm that individually owned businesses (either sole-trader maleowned or sole-trader female-owned) suffer more of any form of credit rationing compared to family- and partnershipowned businesses. The outcomes are also insinuated by Dlova and Simatele (2016) and Ferguson (2012). Firm size also segregates firms by type of credit rationing, again emphasising the effects of size on credit rationing (Kundid \& Ercegovac 2013; Mac et al. 2016). As firm size increases, firms migrate from punitive conditions of crediting rationing to less punitive conditions of credit rationing. As a result, very small firms face more straight denial, but firms become moderately quantity rationed at middle size, and only subjected to more price rationing as they move into mediumsized firms. Even with interactions, firm size transforms the type of credit rationing faced by each type of firm ownership structure from severe direct credit denial to price rationing as firm size increases. However, whatever is the ownership structure, the smaller the firm, the more these consequences of credit rationing are.

In conclusion, there is a need therefore to craft policies that directly focus on addressing gender, racial and firm-size discrimination in finance. The results therefore favour two policy suggestions. One that ties the types of lending technologies to the respective types of funding institutions in order to minimise credit rationing and accelerate credit access. The other is to use firm structures to influence fund allocation based on observed credit rationing constraints in different firm characteristics, notably based on race groups, ownership structure and firm-size credit rationing risk profiles.

\section{Acknowledgements}

The authors would like to acknowledge all the SMMEs that participated in the study as well as participants' contributions at the Management, Business, Administration and Legal Initiative (MBALI) International Conference organised by the University of Zululand in Umfolosi, South Africa between the 1st and 3rd of August 2018.

\section{Competing interests}

No potential financial or personal conflict of interest was reported by the authors which compelled them to write this article.

\section{Authors' contributions}

Both authors equally contributed to the writing of this article. The article originated as part of the PhD work of the first author and was supported by the second author as the research leader of the programme studied.

\section{Funding information}

This article is a result of part of the PhD work of the first author supported by the National University of Science and Technology Research Board under Grant Number $\mathrm{RB} / 132 / 16$.

\section{Data availability statement}

Data sharing is not applicable to this article as no new data were created or analysed in this study.

\section{Disclaimer}

The views and opinions expressed in this article are those of the authors and do not necessarily reflect an official position of their institutions or funders.

\section{References}

Adair, P. \& Fhima, F., 2014, 'Small and medium-sized enterprises' credit rationing on the Tunisian Bank credit market', Journal of Economics and Development Studies 2(1), 81-97.

Allen, T., 2016, 'Optimal (partial) group liability in microfinance lending', Journal of Development Economics 121, 201-216. https://doi.org/10.1016/j.jdeveco.2015. 08.002 
Asiedu, E., Kalonda-Kanyama, I., Ndikumana, L. \& Nti-Addae, A., 2012, 'Access to credit by firms in sub-Saharan Africa: How relevant is gender?', American Economic Review: Papers \& Proceedings 2013(103), 293-294. https://doi.org/ Economic Review: Pap

Aysan, A.F., Disli, M., Ng, A. \& Ozturk, H., 2016, 'Is small the new big ? Islamic banking for SMEs in Turkey', Economic Modelling 54(October 2015), 187-194. https://doi. org/10.1016/j.econmod.2015.12.031

Ayyagari, M., Demirguc-Kunt, A. \& Maksimovic, V., 2011, Small vs. young firms across the world: Contribution to employment, job creation, and growth, World Bank Policy Research Working Paper Series (April), pp. 1-57, World Bank Publications, Washington DC. https://doi.org/10.1596/1813-9450-5631

Bartlett, J.E., Kotrlik, J.W. \& Higgins, C.C., 2001, 'Organizational research : Determining appropriate sample size in survey research', Information Technology, Learning and Performance Journal 19(1), 43-50. https://doi.org/10.5032/jae.2002.03001

Bartoli, F., Ferri, G., Murro, P. \& Rotondi, Z., 2013, 'SME financing and the choice of lending technology in Italy: Complementarity or substitutability?', Journal of Banking and Finance 37(12), 5476-5485. https://doi.org/10.1016/j.jbankfin.2013.08.007

Beck, T. \& Demirguc-Kunt, A., 2006, 'Small and medium-size enterprises: Access to finance as a growth constraint', Journal of Banking \& Finance 30(11), 2931-2943. https://doi.org/10.1016/j.jbankfin.2006.05.009

Berger, A.N. \& Black, L.K., 2011, 'Bank size, lending technologies, and small business finance', Journal of Banking and Finance 35(3), 724-735. https://doi.org/ 10.1016/j.jbankfin.2010.09.004

Berger, A.N. \& Udell, G.F., 2002, 'Small business credit availability and relationship lending: The importance of bank organisational structure', Economic Journa 112(477), 1-36. https://doi.org/10.1111/1468-0297.00682

Berger, A.N. \& Udell, G.F., 2006, 'A more complete conceptual framework for SME finance', Journal of Banking and Finance 30(11), 2945-2966. https://doi. org/10.1016/j.jbankfin.2006.05.008

BKCOB, 2017, Membership directory, BKCOB, East London, viewed 15 June 2017, from http://www.bkcob.co.za/categories.

Butler, M., Kraft, A. \& Weiss, I.S., 2007, 'The effect of reporting frequency on the timeliness of earnings: The cases of voluntary and mandatory interim reports' Journal of Accounting and Economics 43(2-3), 181-217. https://doi.org/10.1016/j. jacceco.2007.02.001

Canales, R. \& Nanda, R., 2012, 'A darker side to decentralized banks: Market power and credit rationing in SME lending', Journal of Financial Economics 105(2), 353-366. https://doi.org/10.1016/j.jfineco.2012.03.006

Casey, E. \& O'Toole, C.M., 2014, 'Bank lending constraints, trade credit and alternative financing during the financial crisis: Evidence from European SMEs', Journal of Corporate Finance 27, 173-193. https://doi.org/10.1016/j.jcorpfin.2014.05.001

Comeig, I., Fernández-Blanco, M.O. \& Ramírez, F., 2015, 'Information acquisition in SME's relationship lending and the cost of loans', Journal of Business Research 68(7), 1650-1652. https://doi.org/10.1016/j.jbusres.2015.02.012

Cotugno, M., Monferrà, S. \& Sampagnaro, G., 2013, 'Relationship lending, hierarchical distance and credit tightening: Evidence from the financial crisis', Journal of Banking and Finance 37(5), 1372-1385. https://doi.org/10.1016/j.jbankfin.2012.07.026

Cowling, M. \& Westhead, P., 2010, 'Bank lending decisions and small firms: Does size matter', International Journal of Enterprenuerial Behaviour and Research 2(2), 52-68. https://doi.org/10.1108/13552559610119331

Degryse, H. \& Van Cayseele, P., 2000, 'Relationship lending within a bank-based system: Evidence from European small business data', Journal of Financial Intermediation 9(1), 90-109. https://doi.org/10.1006/jfin.1999.0278

De la Torre, A., Martínez Pería, M.S. \& Schmukler, S.L., 2010, 'Bank involvement with SMEs: Beyond relationship lending', Journal of Banking and Finance 34(9), 22802293. https://doi.org/10.1016/j.jbankfin.2010.02.014

Dlova, M. \& Simatele, M.C.H., 2016, 'SMME funding criteria in south africa: A comparative review of mainstream and development finance funding', $2015 \mathrm{Globa}$ Development Finance Conference proceedings, Africa growth Institute, Cape Town.

Ferguson, J., 2012, Racism in finance: Major banks issue higher intererst rates to minorities, Citigroup Publications, New York.

Hansen, H. \& Rand, J., 2014, 'The Myth of female credit discrimination in African manufacturing', Journal of Development Studies 50(1), 81-96.

Helsen, F. \& Chmelar, A., 2014, 'The role of collateral in explaining and remediating the limited flow of credit to households and SMEs', in ECRI policy brief: Understanding credit markets for Europe, pp. 1-13, European Credit Research Institute, Brussels.

Hoque, M.Z., Sultana, N. \& Thalil, T., 2016, 'Credit rationing's determinants of Smal and Medium Enterprises (SMEs) in Chittagong, Bangladesh', Journal of Globol Entrepreneurship Research 6(1), 1-23. https://doi.org/10.1186/s40497-016-0045-z
Jiangli, W., Unal, H. \& Yom, C., 2004, 'Relationship lending, accounting disclosure, and credit availability during crisis', Journal of Money, Credit and Banking 40(1), 25-55.

Kano, M., Uchida, H., Udell, G.F. \& Watanabe, W., 2011, 'Information verifiability, bank organization, bank competition and bank-borrower relationships', Journal of Banking and Finance 35(4), 935-954. https://doi.org/10.1016/j.jbankfin. 2010.09.010

Kau, J.B., Keenan, D.C. \& Munneke, H.J., 2012, 'Racial discrimination and mortgage lending, Journal of Real Estate Finance and Economics 45(2), 1-13. https://doi. org/10.1007/s11146-011-9330-3

Kimutai, C.J. \& Ambrose, J., 2013, 'Factors influencing credit rationing by commercia banks in Kenya', International Journal of Humanities and Social Science 3(20), 244-252.

Koreen, M. \& Lucia, C., 2015, 'New approaches to SME and entrepreneurship finance: Broadening the range of instruments', OECD Analytical Report 2015(JT03369708), 15.

Korkeamaki, T., Poyry, S. \& Suo, M., 2014, 'Credit ratings and information asymmetry on the Chinese syndicated loan market', China Economic Review 31, 1-16. https:// on the Chinese syndicated loan market',
doi.org/10.1016/j.chieco.2014.08.001

Kundid, A. \& Ercegovac, R., 2013, 'Credit rationing in financial distress: Croatia SMEs ' finance approach', International Journal of Law and Management 53(1), 62-84.

Luo, D. \& Zhou, J., 2016, 'Financial guarantee for Chinese Rural SMEs based on the theory of credit rationing', Journal of Economics and Development Studies 4(5), 980-983.

Mac, C., Vidal, J.S. \& Lucey, B., 2016, 'Discouraged borrowers: Evidence for Eurozone SMEs', Journal of International Financial Markets, Institutions and Money 44, 46-55. https://doi.org/10.1016/j.intfin.2016.04.009

Makina, D., Fanta, A.B., Mutsonziwa, K., Khumalo, J. \& Maposa, O., 2015, Financial access and SME size in South Africa, Financial Access and SME Size in South Africa, FinMark Trust, Midrand.

Memmel, C., Schmieder, C. \& Stein, I., 2008, Relationship lending - Empirical evidence for Germany, Deutsche Bundesbank, Frankfurt.

Meuleman, M. \& De Maeseneire, W., 2012, ‘Do R\&D subsidies affect SMEs' access to external financing?', Research Policy 41(3), 580-591. https://doi.org/10.1016/j. respol.2012.01.001

Mullen, M., 2012, 'SME finance: Best practice guideline', The Institute of Chartered Accountants in England and Wales 58, 1-16.

Nassr, I.K. \& Wehinger, G., 2014, 'Non-bank debt financing for SMEs: The role of securitisation, private placements and bonds', OECD Journal: Financial Market Trends 2014(1), 139-159. https://doi.org/10.1787/fmt-2014-5jxx05svvw34

Nkuah, J.K., Tanyeh, P.J. \& Kala, G., 2013, 'Financing small and medium enterprises (SMES) in Ghana: Challenges and determinants in accessing bank credit', International Journal of Research in Social Sciences 2(3), 12-25.

NMBBC, 2017, NMBBC task teams, NMBBC, viewed 15 June 2017, from http://www. nmbbusinesschamber.co.za/what-we-do/task-teams.

Ravi, R. \& Hong, Y., 2014, 'Firm opacity and financial market information asymmetry', Journal of Empirical Finance 25, 83-94. https://doi.org/10.1016/j.jempfin. 2013.11.007

SEDA, 2016, 'The small, medium and micro enterprise sector of South Africa', Bereau for Economic Research 1, 1-35.

SEDA, 2017, Small enterprise development agency offerings, viewed 18 July 2017 from http://www.seda.org.za/MyBusiness/SEDAStart/Pages/Introduction.aspx.

Shen, Y., Shen, M., Xu, Z. \& Bai, Y., 2009, 'Bank size and small- and medium-sized enterprise (SME) lending: Evidence from China', World Development 37(4), 800-811. https://doi.org/10.1016/j.worlddev.2008.07.014

Stiglitz, J.E. \& Weiss, A., 1981, 'Credit rationing in markets with imperfect information', American Economic Review 71(3), 393-410.

Trovato, G. \& Alfo, M., 2006, 'Credit rationing and the financial structure if Italian small and medium enterprises', Journal of Applied Economics IX(1), 167-184. https:// doi.org/10.1080/15140326.2006.12040643

Uchida, H. \& Udell, G.F., 2006, 'SME financing and the choice of lending technology', RIETI Research Institute of Economy, Trade and Industry 06, 1-45.

Uchida, H., Udell, G.F. \& Yamori, N., 2012, 'Loan officers and relationship lending to SMEs', Journal of Financial Intermediation 21(1), 97-122.

Viverita, D., Lubis, A.W., Bustaman, Y. \& Riyanti, R.S., 2015, 'Foreign bank entry and credit allocation to SMEs: Evidence from ASEAN countries', Procedia - Social and Behavioral Sciences 211(September), 1049-1056. https://doi.org/10.1016/j. sbspro.2015.11.140 